\title{
Is Quality Management An Islamic Value?^
}

\author{
${ }^{1}$ Ahamad Faosiy Ogunbado, Ph.D., ${ }^{2}$ Asia Mus'ad Al-Otaibi. \\ ${ }^{I}$ School of Humanities and Social Sciences, Albukhary International Unuiversity. Alor Setar, Kedah, Malaysia. \\ ${ }^{2}$ International Institute of Islamic Thought \& Civilization, International Islamic University, Kuala Lumpur, \\ Malaysia.
}

\begin{abstract}
Islam is an all-encompassing creed that does not differentiate between ibadÉt (worship) and muamalÉt (social relations). It governs every aspect of its adherent's life, spiritually, economically, politically as well as socially. The world nowadays is moving towards dynamic global economy; therefore, many managers and leaders of organizations or firms are competitively rushing towards adoption of quality management. In the same vein, many books and scholarly works are available with more discovery everyday; however, Islamic perspective is always lagging behind if not completely neglected. Based on this short background, this paper attempts to fill the gap and answers the question whether quality management is an Islamic value or not. It endeavours to do this through investigating what could be called Islamic values; meaning of management in Islam; the principles and standards lay down in the holy Qur'an, Prophetic Sunnah and relevant Islamic literature in achieving quality. The paper also looks into the quality management from conventional perspective and tries to juxtapose or harmonize the two perspectives. The study is predominantly based on library-oriented research. Materials and data are extracted from books and articles, academic journals, conference proceedings, newspapers and relevant academic websites. However, the Holy Qur'an and Hadith are regarded as the main sources.
\end{abstract}

Key words: Economic, Islamic Value, Quality Management, Social and Spiritual Standards.

\section{Introduction.}

Advancement of science and technology has reduced the whole world to a global village (qariyyah al'alamiyyah). What is going on at the extreme west can be seen at the extreme east, the occurrences in the far north are not hidden issues in the far south. This has given room to competition and innovations in many fields including management. However, the competition from Islamic point of view should not be negative, which is full of envy, hatred or exploitation of others and satisfying one's ego etc. Rather, it should be positive and healthy competition, which entails good production, quality of living in this world and hereafter with ultimate reward of entering the paradise. Allah says, "Be quick in the race for forgiveness from your Lord, and for Garden whose width is that (of the whole) of the heavens and of the earth prepared for the righteous." (AlQur'an, Surah Al-'ImrÉn (3):133.) He also says, "Race with one another for forgiveness from your Lord and garden (paradise) whereof the breath is the breath of the heaven and the earth." (Al-Qur'an, Surah Al-HadÊE (57):21). The field of leadership and management is not left out in this on-going competition. Every company, firm and even the society is yearning for quality management since managerial excellence in anything is the master key to success.

Islam amalgamates all mundane and other aspects of life in the normative bondage of its (Islamic) word view. Quality or excellence matters so much in all endeavours. It is part of Islamic philosophy or cosmology that Almighty Allah (s.w.t) created man as Khalifah (vicegerent or representative) on the earth to manage affairs of the universe as perfectly as possible. It is the role of Khalifah to excellently manage the use of uncountable resources, which Allah (s.w.t) has endowed on the earth in terms of exploration, allocation, production, distribution as well as consumption based on Islamic values. Being a Khalifah or manager is also a test to see who will perfect his or her own part or manage the affairs diligently and extremely well. Allah says that he is the one "who has created death and life, that He may test you which of you is best in deed." (Al-Qur'an, Surah AlMulk (67):2).

Moreover, value is defined as "an ideal accepted by some individual or group." (Electronic Wordweb Dictionary). According to Alhabshi (1994), it is considered as a collective accepted norm. He says:

A value is normally understood to be a thing towards which society has affective regard or even strong belief in its goodness or otherwise. If society has positive affection or strong belief that something is good or beneficial to society, then such a thing is considered to have positive

\footnotetext{
"Earlier version of this paper was presented at International Conference on Da'wah and Islamic Management. Organized by Faculty of Leadership and Management, Universiti Sains Islam Malaysia (USIM) on 23-24 November, 2010.
} 
value examples of positive values are cleanliness, education, generosity, freedom, etc. On the other hand, if society abhors something because either it has no affection for it or does not believe that is of any benefit to it, then that thing is of no value or has negative value. (p.10).

Therefore, Islamic values are the values that are strongly considered as extremely beneficial to the Ummah. Meanwhile, Values in the context of this paper are principles and standards that are considered as good and worthwhile. The paper intends to examine the significant of quality management from Islamic perspective. In an attempt to fulfill this task, the paper begins with the introduction which illuminates the necessity of the quality management, and defines value as it is conceived in the context. It delineates what quality and quality management is; this is done by looking into the conventional and Islamic point of views simultaneously. Brief history of quality management and its development is followed by short description of evolution of quality management. Several principle and standard are enumerated as precisely as the scope of the paper could admit. The paper ends with a summary and conclusion.

\section{What is Quality and Quality Management?}

Quality is a complex term and it is so difficult to be defined due to its complexity. In fact, Arnold and Holler (1994) confirm that if 10 different people were asked to define the term "quality" certainly there would be 10 different answers. This notion is authenticated by American society for quality control which also confirms that "quality" is a subjective term for which each and every concern person has his or her own definition. Nonetheless, according to the society, the term "quality" has two meanings in technical usage (a) the characteristics of a product or service that bear in its ability to satisfy stated or implied needs and (b) a product or service free of deficiencies. (Summers, 2010). Juran and Gryna (1980) define it as "fitness for use" (p.1). It is "conformance to requirements" says Crosby (1979, p.15). Aubery (1985) defines it as "the conformance to standards that represent the product's or service's basic characteristics, and are based on customer needs and expectation."(p.7). According Arcaro (1995) "quality is a structured process for improving the output produced." To him, "it is neither magic nor complex." but "it is based on common sense." (p.55). Above all, Armand Feigenbaum gives a more complete definition of quality as follows:

Quality is a customer determination, which is based on the customer's actual experience with the product or service, measured against his or her requirements- stated or unstated, conscious or merely sensed, technically operational or entirely subjective- and always representing a moving target in a competitive market. (Quoted in Summer, 2010, p.4).

There are several key words in the Feigenbaum's definition which prove how difficult it is to define or determine quality in relation to a particular service or product. The key words should be defined for clarity. Customer determination means only customer determines or decides whether the product or service meet expectations. Actual experience means customer will judge the quality of the service or product by his experience not only at the purchasing time but also throughout the usage of the product or service. Requirement shows that certain aspect of the product or service may be required by the customer directly or indirectly. Technical Operational means that aspect of a product or service may be plainly identified by the buyer, and entirely subjective to the customer personal feelings.

Words like Jawda, Ihsān, ItqÉn as used in Islamic literature refer to quality, perfection or passion for excellence, benevolence or continuous self-evaluation and so on. Furthermore, "ItqÉn" means goodness; it stands for the level of quality work. It means, "to arrange and dispose of things in a scientific and artistic way in order to obtain the most perfect results." (Sheikh, 2000). Ihsān also connotes several meanings, among others, it means murāqaba that is surveillance, control, inspection as in (Allah sees you). "Worship Allah as if you see Him, if you could not see Him He sees you." Ihsān also means doing good to oneself by abiding or eschewing what Almighty Allah commands or forbids. The word means to be nice or perfects the relationship with fellow Muslims and other human beings, in other words, it means an inclination to do kind or charitable acts, or act intending or showing kindness and good will; to perform more than what is required. Above all, it means perfection in any undertakings or spheres of life. (Ibid). It is reported that one of Prophet Munhammad (s.a.w) sayings implies that "Ihsān signifies complete concentration in the performance of the devotional duty to the extent that one should realise that Allah is always watchful of all His servants in the performance of their devotional act." (Alhabshi, 1996, p.166). "I Ihsān is to increase one's perfection to be good manager both in the sense of proficiency and efficiency in the actual practice of management." (Alburaey, 2005, p. 41).

Furthermore, Quality Management is a wholistic approach where qualities of human resources precede, intermingling with quality input and quality process to achieve quality output. (Ahmed, 1996). It is defined as the "efficient management of organization, which in turn meets customers' needs efficiently." (Ibid, 238). However, Islamic Management is defined thus: 
Islamic management is the process of planning, organizing, leading and controlling the efforts of organizational members and of using all other organizational members and of using all other organizational resources depending upon the guidance of Allah (SWT) and his Prophet (SAW) with an accountable mentality, integrity and skill to achieve the predetermined objectives. (Mohiuddin, 2006, p.16).

\section{History of Quality Management and its Development.}

Edwards Deming was first introduced to the basic tents of traditional management principles at Western electric plant in Chicago as an employee in the late 1920s. His experience at this company aroused his curiosity on "how can firms best motivate their employees?" this is because he found the existing system economically unproductive. (Arcaro, 1995). Walter Shewhart was another expert in quality control. He was assigned by Bell laboratory to study quality related problems. Consequently, he produced a book entitled "The Economic Control of Quality of Manufactured Products" in 1931. The book is considered as a landmark contribution to the attempt to develop excellence of manufactured goods. He developed control chart to monitor the product and to enable workers to detect when they are about to exceed limit and possibly produce scrap. Shewhart' work gained popularity among the British statisticians and was invited in 1932 to lecture at the University of London. (Sohod and Yusof, 1996; Abdullah 1996).

Deming was impressed with Shewhart's work. The former visited the latter and employed the latter's technique in his work with U.S. Census Bureau Institute. Deming, during the Second World War taught Shewhart's techniques to thousand of engineers who participated in war materials production. In 1947 he welcomed Japan's invitation and helped them in preparation for national census. He delivered series of lectures in many economic sectors in Japan, his quality methodology and philosophy was wholeheartedly welcomed. (Arcaro, 1995). Henceforth, he found his place in the Japanese society.

Joseph M Juran like Deming was equally recognized as one of the "fathers of quality." He was also familiar with Shewhart's work and assisted in restructuring the Japanese industries. He defined Quality as "fitness for use" (Ibid, p.5) and pointed out that it has five dimensions. In 1979, Philip B. Crosby was famed by his book "Quality is Free". His approach to quality is built around 4 fundamental beliefs, which he calls "absolute." (Sohod and Yusof, 1996, pp. 80-1).

Be that as it may, looking into the history of quality, one finds out that quality is new baby in the Western history. Whereas, it has been incorporated or part and parcel of Islamic civilization since 15 centuries ago. Many verses in holy Qur'an talk about and encourage quality and perfection in all endeavours. Almighty Allah created heaven, earth and what is in between, both living and non-living in the perfect manner, best quality. "Who has perfected everything he created". ( Al-Qur'an, Surah al-Sajidah (32):7). Also, "Verily, we created man in the best stature (mould)." (Al-Qur'an, Surah Al-Tin (95):4). Maududi in his explanation of the former verse says:

In this limitless universe He has created countless number of things, but none of them is ugly and ill-shaped: everything has its own special beauty: everything is proportionate and symmetrical in its own way. Whatever He has made for a particular purpose, He has given it the most appropriate form and invested it with the most suitable qualities for it. No better and more appropriate structure could be conceived, for example, for the eye and the ear which have been made for seeing and hearing. The air has precisely the same qualities which it should have for the purpose for which it has been made, and the water precisely the same qualities for the purpose for which it has been made. No one can point out any defect or flaw in the design of anything made by God; nor can anyone offer an alteration or modification in it. (Maududi, 2007, v.4 p.45).

Therefore, Islam advocates striving for excellence, attaining quality and sticking to perfection in all undertakings, whether spiritual or mundane. Many of Prophet Muhammad's traditions were recorded persuading and urging for quality.

Verily Allah has prescribed proficiency in all things. Thus, if you kill, kill well; and if you slaughter, slaughter well. Let each of you sharpen his blade and let him spare suffering to the animal he slaughter. (Al-Nawawi, n.d, Hadith no.17).

Tradition also recorded that Prophet Muhammad (s.a.w) said "Indeed Allah loves one who does work, he does it with itqÉn." (Tabrani, book 1 p. 275 no 897). Somebody who shows perfection, excellence in his or her deeds towards the creator, as well as, to fellow human.

In twentieth century, globalization became more popular. All the nations are now living in a global village. This gives rooms to competition in every fields and sectors; economically, politically, socially, 
educationally and so on. Therefore, to win these competitions is to improve the products and customer services through the quality management.

\section{Evolution of Quality Management.}

The concept of quality has been evolved over the years from Quality Control (QC) to Quality Assurance (QA), to Quality Management (QM) and later to Total Quality Management (TQM). During the preliminary stage of quality, which is quality control (QC) the focus was based on inspection and measurement of results. The system is applied to imported goods, manufactured components used at a period of manufacturing progression. At this stage, inspection was not only directly concerned with supplier and customer but also focused on products that are not conform to the specifications or requirements stipulated. Furthermore, under advanced quality control, product testing, process performance data and feedback are usually essential. Defining quality as the "absence of variation in output" (Abdullah, 1996, p.56) covers this paradigm.

The development in quality reaches its next stage called Quality Assurance; this time around, the concern is on statistical analysis that focuses on problem definition and process improvement. Quality assurance accommodates systematic prevention-based approach to quality more than quality control. This stage also gains upper hand by using comprehensive quality manual, limited use of quality cost, use of Statistical Process Control (SPC) and auditing of quality system. The best definition to this stage is "quality is conformance to high standards." Furthermore, another stage comes to existence; this is called Total Quality Management (TQM), which is otherwise known as Continuous improvement (CI). Here, the focus is on four dimensions (1) employee empowerment, (2) team accountability, (3) Customer-supplier focus, and (4) speed. The focus is more on users of a product and service. (Ibid).

\section{Principles and Standards.}

There are several principles and standards, which Islam lays down, in order to achieve quality management. However, few that are enumerated below are all supported by either Al-Qur'an or Hadith and other relevant Islamic sources. They are all practiced by the Holy Prophet Muhammad (s.a.w) and his rightly guided caliphs.

Trustworthiness and Honest:- this is one of the most important principles in Islamic management. Trustworthiness is the duties man is entrusted with, be it sacred or worldly. It means not likely to steal, cheat or lie. The manager should be honest in his or her dealings. He or she should display honest in his or her endeavours so that the subordinates can emulate. Allah says "O ye that believe! Betray not Allah and His Noble Messenger, nor misappropriate knowingly things entrusted to you." (Al-Qur'an, Surah Al-AnfÉl (8):27). The Prophet (s.a.w) used to guide Muslims to adhere to trustworthiness and honesty in every respect. He also emphatically reminds them in his public speeches, sermons, and directives. Anas Ibn-Maalik reported, "Rarely would Prophet Muhammad (s.a.w.) give a speech without saying "There is no faith for he who lacks trustworthiness and there is no religion for he who can't keep a vow." (Reported by Ahmad). The Prophet also urges not to betray the one who betrays you; he says: "Render back trusts to the one who entrusted you, and do not betray the one who betrays you." (Reported by Abu Daa'uud and Ibn Maajah).

Strong Will and Self-Determination: Strong will and self-determination are highly connected with the concept of quality management and they are considered among the most prominent ways to have access to all forms of sustainable development and sound progress. The fact is that discovering the truth behind quality management and probing its depth depends in the first place on how wide is the scope of man's vision. The Almighty Allah encourages the true believers to have strong will and self-determination so as to achieve their goals. The Almighty Allah says "when thou hast taken a decision, put thy trust in Allah for Allah love those who put their trust (in Him)." (Al-Qur'an, Surah Ól-'Imrān (3):159.). The Prophet (s.a.w) also says: "The strong believer is better and more beloved to Allah than the weak believer, while there is good in both.”(Reported by Ibn Maajah).

Efficiency: Islam requires efficiency in everything. One should be effective or able to accomplish his mission without wasting time, effort and fund. Allah says that He loves dexterous and efficient workers. Holy Prophet Muhammad (s.a.w) always preaches to his followers to be efficient in their undertakings be it religious or worldly, minor or major. Abu-bakr also emulates his master in efficient management of his Ummmah, likewise other rightly guided caliphs. It has been recorded that the Prophet said:

Allah has ordered to complete every action in a better way, when you slaughter (animal) do it in a best way, so everyone of you should sharpen his knife, and let the slaughtered animal die comfortably. (Reported by Muslim).

Murāqabah (Supervision) is one of the paramount principles of quality management in Islam. In the definition of Ihsān earlier stated, we said that it also means murāqaba that is surveillance, control, and 
inspection as in (Allah sees you). Hence, "Supervision is the innermost feeling that one gets from respecting the fact that the Almighty Allah is ever seeing, ever watching and has His eyes on a person at all time and place." (Saleh, 2002, p.70). It is obligatory upon every Muslims to be Allah-conscious, in all of his or her activities. Muslim should execute the work that is entrusted to him or her with utmost perfection, having in mind that the Supreme Supervisor (Allah) watches over him, even though he or she cannot see the Almighty Allah.

Supervision can be viewed from two directions, self supervision and supervision over others. Self supervision takes place when a person checks himself whether he or she is doing the right thing or not. Supervision of others is to check or oversee the people that were given task to execute. That is, keep surveillance on the activities of delegates or representatives in other to appreciate their good job or to correct their mistakes. A typical example of this could be seen from 'Umar bin Khattāb's administration. He used to give his governors and agents free rein in their task; notwithstanding, he was very strict in supervision. One day he asked those who were around him:

What do you think, if I were to appoint over you the best one I could find, then command him to be just, would I have done what is required of me?" they said "yes" he said "No, not until I see how he does it, and whether he will do what I have commanded him or not." (Quoted in asSallabi, 2007, p.80).

It is also reported that he said:

Allah is testing you by means of me and is testing me by means of you, and he has kept me alive after my two companions are gone. None of your affairs that I witness will I let anyone deal with, and none of your affairs that I do not witness but I will strive hard to ensure that they are dealt with. If the governors do well, I shall reward them but if they do badly, I shall punish them. (ibid, p.105).

Muhāsabah (Accountability) is defined as a self-control that enables a person to judge his or her deeds or attitudes for which he or she will be asked in the Hereafter. (Saleh, 2002). The feeling of accountability inspires Muslim managers as well as the workers to excel in their productions and services. The Holy Qur'an makes it clear that everyone is responsible and accountable for his or her deeds. It says: "Every soul will be (held) in pledge for its deeds." (Al-Qur'an, Surah An-NisÉ (74):38). Yusuf 'Ali comments on this verse as follows:

Man cannot shift his responsibility to vicarious or saints. His redemption depends upon the grace of AllÉh, for which he should constantly and whole-heartedly strive by means of right conduct. If he does so he will be redeemed and will join the companion on of the right hand. ('Ali, 2005, p1852)

Al-Qur'an also says:

Then shall anyone who has done an atom's of weight of good, see it. And anyone who has done an atom's weight of evil, shall see it. (Al-Qur'an, Surah Al-Zalzalah (99):7-8)

And,

Verily, no bearer of burdens can bear the burden of another. That man can have nothing but what he strive for. (Ibid., Surah Al-Najm (53):38-39).

Since earlier days of Islam, Prophet Muhammad (s.a.w) always employed the principle of accountability and check and balance to supervise the income or revenue and expenditure of the provinces and their officers. One day, a tax collector returned to Medina with the tax revenue and told the Prophet that some of the revenue was given to him as gifts. The Prophet then replied,

What is wrong with the man whom we appointed as a tax-collector and he said this is for you and that was given to me? If he stayed in his parent's house, would something be given to him? The prophet then added, whomsoever we appointed over an affair, we will give him provision. What he takes after that is breach of trust. (Quoted in al-Buraey, 1985, p.245).

By the same token, 'Umar Ibn KhattÉb employed the principle learnt from his master and emphasized the importance of self-accountability in his statement "judge yourselves before you are judged; and prepare for the Day of Judgment. Remember that accountability in the world hereafter is easier for he who accounts for his conduct in the world." (Al-Banna, 1985, p.124).

Division of Labour is one of the core principles in Quality Management. It was reported that Prophet Muhammad (s.a.w) used the principle of division of labour to achieve proper execution, direction of administrative activities, planning and integration of the competency in managing the Islamic state established at Medina. Ibn KhaldËn also views that, large population through specialization and division of labour creates 
wealth. That is to say, economic progress occurs when political expansion leads to large-scale production based on the specialization or division of labour. He says:

...a single individual is incapable of satisfying his needs by himself, but must cooperate with other members of society. The product of such cooperative labour will exceed by far the needs of the group. Thus, in the production of wheat for example, we do not see each individual providing for his own needs; rather we see six or ten persons cooperating: a blacksmith, a carpenter to repair tools, an ox-tender, a man to plough the soil and another to reap the grain; and so forth for the different kinds of agriculture work, each man specializing in one operation.....the result of such cooperative labour is to produce a quantity of food which is sufficient for many times the number of person engaged in the work. (Issawi, 1950, 92-3).

Collective Efforts: As Islam encourages division of labour, it also promotes collective efforts as a principle for quality management. That is to say, Islam encourages cooperation among all individuals in order to achieve excellent performance. Each worker contributes his own quota for the benefit of the company and for the betterment of the production. Organizations are usually effective if they are able to crystallise good teamwork. Almighty Allah adores collective works as He says in the Holy Qur'an, "Truly Allah loves those who fight in His cause in the battle array, as if they were solid cemented structure." (Al-Qur'an, Surah Al-Saff (61):4). Allah has encouraged Muslims to hold firmly of his tutelage in any circumstances and not mutually separated "And hold fast, altogether, by the rope which Allah (stretches out for you), and be not divided among yourselves." (Al-Qur'an, Surah Ól-'ImrÉn (3):103).

The management should make sure that environment is conducive for everyone to feel sense of belonging and to believe that he or she is an asset to the firm, organization or community. This can only yield in having good teamwork. Teamwork or collective efforts stem from good relationships. Islam strongly recommends these relationships, which are nourished by feelings, belief and trust in one another and intimacy as well as brotherhood.

Planning is a crucial principle in quality management. It is an act of formulating a policy for a definite course of action. It is also an act or process of drawing up plans or layouts for some project or enterprise. Planning has to do with the cognitive process of thinking about what you will do in the event of something happening. Planning involves selecting mission and objectives and the action to achieve them; it requires decision making, which is, choosing from the alternative among the future courses of action. (Koontz and Weihrich, 1994). It is also indicated that:

Planning encompasses the definition of organisational objectives or goals, the establishment of an overall strategy of how to achieve these objectives and the development of a comprehensive hierarch of plans integrating and coordinating the various activities. The concern is thus with the ends as well as with the means. (Ahmad, 2009, pp.82-3).

Islam recommends that mission should be set so as to achieve the vision, if there is no set mission, vision attainment will be unrealistic. Prophet Muhammad (s.a.w) as a model of great managers used to plan for his action based on Qur'anic injunctions. The Qur'an says, "O ye who believe! Fear Allah and let every soul look to what (provision) he has sentforth for the morrow. Yea, fear Allah for Allah is well-acquainted of (all) that ye do." (Al-Qur'an, Surah Al Hashr (3):159) Planning from Islamic point of view requires four basic principles, as Ahmad (2009) categorically states, (1) Planning for the future based on the previous experience in order to avoid failure. (2) Rational use of resources, this means that management should be able to identify potential resources at their disposal and artistically plan how to use it in order to produce the desired result. AlQur'an says, "Do you not see that Allah has subjected to your use all things in the heaven and on earth and has made his bounties flow to you in exceeding measure both seen and unseen" (3) Consultation before decision making, seeking advice and mutual consultation is very crucial in planning. AllÉh says, "Consult them in affairs." (Al-Qur'an, Surah Al-'ImrÉn (59):18). “... who conduct their affairs in mutual consultation.” (AlQur'an, Surah Al-shËrÉ (42):38). (4) Fairness to others, this has to do with sense of justice, justice to oneself and to others. There should be balance in distribution tasks and responsibilities. The manger should ensure that no extra burden is enforced upon the workers. Al-Qur'an says, "On no soul doth Allah place a burden greater than it can bear" (Al-Qur'an, Surah Al-Baqarah (2):286). The Prophet says:

Your servants and slaves are your brothers. Allah has put them in your care, so feed them with what you eat, clothe them with what you wear. and do not burden them beyond their capacities; but if you burden them (with an unbearable burden), then help them (by sharing their extra burden). (Shahih Muslim, Book15, Hadith 4092). 
Preference to the Organisational Interest: In order to achieve quality management, organizational interest should be given priority above individual interest. In other words, one should think about what the company or organisation will benefit from him or her before thinking of what he or she will benefit from the company. However, interest should be two ways; it should be "give and take". As one protects the interest of the company, the company also has to protect the interest of its workers. It was reported that "Umar Ibn Abdul Azeez used to write on the right angle of his officers application "write less with public papers and pen, waste less ink, and no illegal facilities will be achieved by any means." (Quoted in Mohiuddin, 2006, p.28).

Right person in the right place: In order to achieve quality management, Islam advises that the right leg should be put in the right shoe. That is competent and suitable person should be appointed into the suitable place or post. It was reported that Prophet Muhammad said "one who appointed an incompetent person to a responsible post as though has betrayed Allah and his Prophet".(Al-Bukhari). By the same token, "Ali bin Talib counsels al-Ashtar al-Nakh'i who was one of his governors to select the best person to the posts. He says:

Choose the best of your subjects, in your view, for the office of arbitration between people. The one who is fully aware of the issues of litigation. A person with whom the adversaries cannot quarrel nor persist in their depravity; but would turn back to the truth if it is proved; a man who is not greedy and is more deliberated and analytical in controversial matters; one more inclined to proof than subjectivity; one who is less likely to be annoyed with adversaries' complaints; one who is more patient to inquire into the matters; one who is more inclined to the truth if it appears not influenced by appearance or the performance and incitement of his adversaries. (Abi Talib, 1963, vol.2, p.221)

\section{Summary and Conclusion.}

The paper attempts to examine whether quality management is recognized or has its root in IslÉm or not. It emphasizes that Islam is not a religion that confines itself to only rituals but it is a comprehensive way of life that unifies mundane and spiritual aspect of the human being together. Nowadays that the world is a small village through the advancement of science and technology, every society or community is heading towards quality management. There is a competition towards excellence in management. It is spelt out from the discussion that Islam had laid emphasis on quality management since its inception and therefore calls for such positive competition in various filed for the betterment of the Ummah.

The study covers the definitions of quality and quality management together with brief background of quality and its development. Several principles and standards, which are recognized as Islamic values are itemized. Although, the cataloged principles and standards are just few out of many; others can also be found in other Islamic literatures. All in all, Islam encourages quality in all its adherences' endeaviours. Likewise, as Khalifah or vicegerent on the earth, man is tasked with the responsibility of quality management.

\section{References.}

[1] Abdullah, M. (1996). "Historical developments of quality and productivity movement: Japan vs. The west." in A.M. Sadeq \& A..K. Ahmad (Eds.), Quality management: Islamic Perspective, (pp.55-68). Kuala Lumpur: Leeds Publications.

[2] Ahmed, A. (1991). "Moral and spiritual development and its implications for the curriculum: A Muslim perspective." Muslim Education Quarterly, 16(4), 61-67.

[3] Ahmad, A. K. (1996). "Case study on the Malaysian version of total quality management" in A.M. Sadeq \& A..K. Ahmad (Eds.), Quality management: Islamic perspective, (pp.238-257). Kuala Lumpur: Leeds Publications.

[4] Ahmad K. (2009). Management from an Islamic perspective Kuala Lumpur: Prentice Hall.

[5] Al-Banna, F. Abdul-Basit (1985). Al-Takhtit- dirasah fi majal al-idarah al-Islamiyyah wa al-idarah al-'ammah Cairo: AlMu'assasah Al-Arabiyyah Al-Hadithah

[6] Al-Buraey, M. A. (2005). Management principles derived from the sources of Islam" in Mazilan Musa and Shaikh Mohd Saifudden Shaikh Mohd Salleh (Eds). Quality Standard from Islamic Perspective, (pp.27-41). Kuala Lumpur: Institute of Islamic Understanding Malaysia (IKIM).

[7] 'Ali, 'A. Y. (2006). The Meaning of the Holy Qur'an, New edition with revised translation, commentary and newly complied comprehensive index. Maryland: Amana Publication

[8] Alhabshi, S.O. and Ghazali, A.H. (Eds.) (1994). Islamic values and management, Kuala Lumpur: Institute of Islamic Understanding Malaysia (IKIM).

[9] Alhabshi, S. O. (1996). "Quality and productivities consciousness: An Islamic approach" in A.M. Sadeq \& A..K. Ahmad (Eds.), Quality management: Islamic perspective, (pp.155-187). Kuala Lumpur: Leeds Publications.

[10] Ali, A. (1902). The Spirit of 'Islam': a History of the evolution and ideals of 'Islam' with life of the Prophet. Calcutta : S. K. Lahiri.

[11] Arcaro, Jerome S. (1995). Quality in Education: An implementation handbook. Florida: St.Lucie Press.

[12] Â̂-s-Sallabi, 'A. Muhammad (2007). 'Umar Ibn Khattäb:His life and times. Trans. Nasiruddin al-Khattāb. Riyadh: International Islamic Publishing House.

[13] Aubrey, C. (1985). Quality Management in financial service, Wheaton: Hitchcock Publishing Co.

[14] Arnold K. L. and Michael, H. (1994) Quality assurance: Methods and technology. New York: Glencoe-McGraw-Hill.

[15] Sheikh, Badawi Muhamud (2000), Al-Jawda al-sāmilah fi al-'amal al-islamiy, Cairo:DÉr al-fikr al-arabi.

[16] Bloom, A. (1998). Closing of the American mind. New York: Simon and Schuster.

[17] Bose, S., \& Jalal, A. (1998). Modern South Asia: History, culture, political economy. London: Routledge

[18] Crane \& Barrier (eds.) (1981). British Imperial policy in India and Sri Lanka, 1858-1912: A Reassessment. Delhi: Heritage Publishers. 
[19] Crosby, P. (1979), Quality is Free, New York: McGraw-Hill.

[20] Ellis, R. (1994), "Quality assurance for university teaching: Issues and approaches", in. R. Ellis. Quality assurance for University teaching. Buckingham: Open University press.

[21] Haque, M. (2002). "Review of the progress of Islamic Education." Muslim Education Quarterly, 19(4), 68-73.

[22] Harman, G. and Meek, V.L. (2000). Repositioning quality assurance and accreditation in Australian Higher Education. Canberra: DETYA. Also available at: http://www.detya.gov.au/highered/eippubs/eip00_2/fullcopy00_2.pdf

[23] Hewitt, I. (1997). "The Need for the state funded (VA \& GM) Muslim schools" in Religious education: A Muslim perspective. London: National Muslim Education Council for UK.

[24] Issawi, C. (1950). An Arab Philosophy of History, Selection from Prolegomena of Ibn Khaldūn of Tunis (1332-1406), London: John Murray.

[25] Juran, J. and Gryna, F. (1980), Quality planning and analysis, New York: McGraw-Hill.

[26] Koontz H. and Weihrich H. (1994). Management: A Global Prospective. Singapore: Mc Graw-Hill.

[27] Lim, David (2001). Quality Assurance in higher education: A study of developing countries, Aldershot: Ashgate.

[28] Mohiuddin, M. G. (2006). Islamic management. Dhaka: the University Grants Commination of Bangladesh.

[29] Mottahedeh, R. (1986). The Mantle of the Prophet: Learning and power in modern Iran. London: Chatto \& Windus.

[30] Mukadam, M . (1997). "Religious Education and the Muslim Children at state schools" in Religious Education: A Muslim Perspective. London: National Muslim Education Council of UK.

[31] Parkinson, C.N., Rustomji, M.K. and Sapre, S.A., (1986) Great Ideas in management, Kuala Lumpur: Federal Publications.

[32] Salam, El Fatih (2001). "From Documentary-Empirical to the Integrated Methodology of Research in Political Science: A Comparison between the Secular Western and Islamic Approaches." Muslim Education Quarterly, 19(1), 4-17.

[33] Saleh M. J. (2002). Education administration: An Islamic perspective. Kuala Lumpur: A.S.Noordeen

[34] Sohod M. S. and Yusof R. Z. (1996). "Re-addressing the TQM movements: Towards an Alternative Model" in A.M. Sadeq \& A.K. Ahmad (Eds.), Quality management: Islamic Perspective, (pp.69-96). Kuala Lumpur: Leeds Publications. 